\title{
Effect of penehyclidine hydrochloride on $\beta$-arrestin-1 expression in lipopolysaccharide-induced human pulmonary microvascular endothelial cells
}

\author{
J. Zhan ${ }^{1 *}$, F. Xiao ${ }^{2 *}$, Z.Z. Zhang ${ }^{1}$, Y.P. Wang ${ }^{1}$, K. Chen ${ }^{1}$ and Y.L. Wang ${ }^{1}$ \\ ${ }^{1}$ Department of Anesthesiology, Zhongnan Hospital, Wuhan University, Wuhan, Hubei, China \\ ${ }^{2}$ Department of Osteology, Pu Ai Hospital, Huazhong University of Science and Technology, Wuhan, Hubei, China
}

\begin{abstract}
$\beta$-arrestins are expressed proteins that were first described, and are well-known, as negative regulators of $\mathrm{G}$ protein-coupled receptor signaling. Penehyclidine hydrochloride $(\mathrm{PHC})$ is a new anti-cholinergic drug that can inhibit biomembrane lipid peroxidation, and decrease cytokines and oxyradicals. However, to date, no reports on the effects of PHC on $\beta$-arrestin- 1 in cells have been published. The aim of this study was to investigate the effect of PHC on $\beta$-arrestin- 1 expression in lipopolysaccharide (LPS)-induced human pulmonary microvascular endothelial cells (HPMEC). Cultured HPMEC were pretreated with PHC, followed by LPS treatment. Muscarinic receptor mRNAs were assayed by real-time quantitative PCR. Cell viability was assayed by the methyl thiazolyl tetrazolium (MTT) conversion test. The dose and time effects of PHC on $\beta$ arrestin-1 expression in LPS-induced HPMEC were determined by Western blot analysis. Cell malondialdehyde (MDA) level and superoxide dismutase (SOD) activity were measured. It was found that the $M_{3}$ receptor was the one most highly expressed, and was activated 5 min after LPS challenge. Furthermore, $2 \mu \mathrm{g} / \mathrm{mL}$ PHC significantly upregulated expression of $\beta$-arrestin-1 within 10 to $15 \mathrm{~min}$. Compared with the control group, MDA levels in cells were remarkably increased and SOD activities were significantly decreased in LPS pretreated cells, while PHC markedly decreased MDA levels and increased SOD activities. We conclude that PHC attenuated ROS injury by upregulating $\beta$-arrestin-1 expression, thereby implicating a mechanism by which PHC may exert its protective effects against LPS-induced pulmonary microvascular endothelial cell injury.
\end{abstract}

Key words: Penehyclidine hydrochloride; Human pulmonary microvascular endothelial cells; $\beta$-arrestin-1

\section{Introduction}

Oxidative stress is an imbalance between oxidants and antioxidants (1). Oxidative stress can cause serious damage to cellular structure and function, and can also modulate cell signaling pathways and gene expression. Biological lipid oxidation produces oxidative stress. Malondialdehyde (MDA) is the principal product of polyunsaturated fatty acid peroxidation. This aldehyde is a highly toxic molecule and should be considered as more than just a marker of lipid peroxidation (2). Superoxide dismutase (SOD) is an endogenous enzyme responsible for the dismutation of superoxide radicals. SOD plays a pivotal role in protecting tissues from damage by oxidative stress by scavenging superoxide anions, which prevents the formation of other more potent oxidants such as peroxynitrite and hydroxyl radicals (3).

Arrestins are expressed proteins that were first described, and are well-known as negative regulators of G protein-coupled receptor (GPCR) signaling (4). There are four members of the arrestin family (arrestin-1 to -4 ). Arrestin-1 and arrestin-4, termed rod and cone arrestin, are expressed in photoreceptor cells and terminate rhodopsin and cone opsin signaling. Arrestin-2 (also called $\beta$-arrestin-1) and arrestin-3 (also called $\beta$-arrestin2) are ubiquitously distributed and bind hundreds of different GPCRs $(5,6)$. Arrestins play key roles in the regulation of multiple GPCR-dependent and -independent

Correspondence: Y.L. Wang, Department of Anesthesiology, Zhongnan Hospital, Wuhan University, Wuhan 430071, Hubei, China. E-mail: jia19811001@163.com

${ }^{*}$ These authors contributed equally to this study.

Received June 8, 2013. Accepted September 12, 2013. First published online December 2, 2013. 
signaling pathways. Arrestins bind to the activated and phosphorylated state of these receptors, consequently blocking the ability of the receptors to activate $G$ protein (7). $\beta$-arrestin-1 serves as a multifunctional adaptor protein that mediates receptor desensitization, receptor internalization, and links GPCRs to downstream pathways (8). Studies have also shown that, depending on the cellular context and receptor examined, $\beta$-arrestin- 1 either mediates or inhibits receptor signaling (9). Furthermore, recent studies have also shown that $\beta$-arrestins function to negatively regulate the inflammatory response induced by lipopolysaccharide (LPS) (10). It has also been demonstrated that $\beta$-arrestins can regulate LPS-induced signaling and pro-inflammatory gene expression (11).

Penehyclidine hydrochloride $(\mathrm{PHC})$ is a new anticholinergic drug derived from hyoscyamine, which is an anticholinergic agent with a high degree of selectivity for $M_{1}$ and $M_{3}$ receptor subtypes (12). PHC could improve the outcome in patients with soman poisoning, and appears efficacious in improving the symptoms and the lung function of patients with chronic obstructive pulmonary disease, a lung disease defined by persistently poor airflow as a result of breakdown of lung tissue and dysfunction of the small airways $(13,14)$. Other than the anticholinergic effects, PHC could inhibit biomembrane lipid peroxidation, and decrease cytokines and oxyradicals. Shen et al. (15) reported that $\mathrm{PHC}$ counteracted lipid peroxidation as indicated by reduced MDA content and increased activity of SOD. Moreover, our recent studies demonstrated that $\mathrm{PHC}$ could attenuate NO production and iNOS expression by suppressing the activation of the p38 MAPK pathway, and that $\beta$-arrestin-1 is closely related to p38 MAPK signaling pathway $(16,17)$. However, to date, no reports on the effects of PHC on $\beta$-arrestin-1 in cells have been published. This study aimed to investigate the effect of PHC on $\beta$-arrestin- 1 expression in LPS-induced human pulmonary microvascular endothelial cells (HPMEC), and explore the biological effect of PHC on LPS-induced MDA production and SOD activity in HPMEC in order to lay a solid foundation for future research of $\mathrm{PHC}$ in cells.

\section{Material and Methods}

\section{Material}

PHC was provided by Lisite Corporation (China). LPS (Escherichia coli 0111: B4) and RPMI 1640 were purchased from Sigma (USA). MDA and SOD assay kits were purchased from Jiancheng Biologic Project Company (China). Anti- $\beta$-arrestin-1 antibody was purchased from Abcam Incorporated (UK) (rabbit, Ab32099, 1:1000) and anti- $\beta$-actin antibody was provided by Santa Cruz Biotechnology (USA) (rabbit, Sc-1616r, 1:1000).

\section{Cell lines and cell culture}

HPMEC were purchased from the Type Culture Collection of the Chinese Academy of Sciences (Shanghai,
China) and were cultured in RPMI 1640, 10\% standard newborn calf serum, $50 \mu \mathrm{g} / \mathrm{mL}$ streptomycin, $50 \mathrm{IU} / \mathrm{mL}$ penicillin, and $2 \mathrm{mM}$ glutamine in a humidified, $5 \% \mathrm{CO}_{2}$

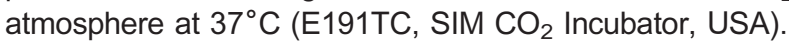

\section{Real-time quantitative PCR analysis}

Cells were harvested and total RNA was extracted using Trizol Reagent (Invitrogen Life Technologies, USA) according to the manufacturer's instructions. Two micrograms total RNA was reverse transcribed using a Toyobo First-Strand cDNA synthesis kit (GeneCopoeia Inc. USA). Reverse transcription was performed at $70^{\circ} \mathrm{C}$ for $5 \mathrm{~min}, 0^{\circ} \mathrm{C}$ for $3 \mathrm{~min}, 42^{\circ} \mathrm{C}$ for $30 \mathrm{~min}$, and $80^{\circ} \mathrm{C}$ for 5 min. The mRNA levels of $M_{1}, M_{2}, M_{3}$, and $M_{4}$ receptor subtypes were measured by quantitative PCR. QPCR amplifications were performed in triplicate using the SYBR Green I assay (Toyobo Inc., Japan). The reactions were carried out in $25-\mu \mathrm{L}$ reaction solution containing $2.0 \mu \mathrm{L}$ cDNA, $2.0 \mu \mathrm{L}$ mixed gene-specific forward and reverse primers (10 mM each), $12.5 \mu \mathrm{L} 2 \times$ qPCR Mix and $8.5 \mu \mathrm{L}$ double-distilled $\mathrm{H}_{2} \mathrm{O}$. The amplification reaction was carried out in an initial 1-min predenaturation at $95^{\circ} \mathrm{C}, 40$ cycles at $95^{\circ} \mathrm{C}$ for $15 \mathrm{~s}, 58^{\circ} \mathrm{C}$ for $20 \mathrm{~s}, 72^{\circ} \mathrm{C}$ for $20 \mathrm{~s}$, followed by the protocol for the melting curve with an increase of $1^{\circ} \mathrm{C}$ between each $20 \mathrm{~s}$ from $72^{\circ}$ to $95^{\circ} \mathrm{C}$. $\beta$-actin gene was used as an internal control for normalization of RNA quantity and quality differences in all samples. For each sample analyzed, qPCR provides a cycle time (CT) value where the fluorescence signal is detectable. All CTs were dependent on the starting amount of cDNA. The $\beta$-actin CT value was used to confirm the starting amount of cDNA in PCR quantifications. Gene expression was quantified using a modification of the $2^{-\Delta \Delta \mathrm{Ct}}$ method.

Primer sequences were designed using the NCBIPrimer BLAST online tool and synthesized commercially (Invitrogen Biotechnology Co., Ltd., China). The sequences of the primers used in the present study were as follows: $M_{1}$, CTCTTTCAAGGTCAACACGGAGTCACGGAGAAGTAGC GGT 241 bp (NM_000738); $M_{2}$, CATCAACAGCACTAT CAACCCCCTTGCCCACCTTCTATCTT $145 \mathrm{bp}$ (NM 001006630); $\mathrm{M}_{3}$, TCTTGCTTGCCTTCATCATCACCGA $\bar{C}$ TGTCTCTGCTGGTA 250 bp (NM_000740); M4, ACACT TCCAATGAGTCCAGCGTCTGCTTCGTCACAATCTG 175 bp (NM_000741); $\beta$-actin, GTCCACCGCAAATGCTT CTATGCTGTCACCTTCACCGTTC 190 bp (NM_001101).

\section{Cell viability assay}

Cell viability was assessed by the methyl thiazolyl tetrazolium (MTT) conversion test. Briefly, HPMECs were seeded on 96 -well microtiter plates $(20,000$ cells/well) and allowed to adhere for $24 \mathrm{~h}$. The cells were incubated without or with $\operatorname{PHC}(0.2,1,2,10,20,100,200 \mu \mathrm{g} / \mathrm{mL})$ for $1 \mathrm{~h}$ followed by induction with LPS $(0.1 \mu \mathrm{g} / \mathrm{mL})$ for $24 \mathrm{~h}$. We also added a PHC alone group $(200 \mu \mathrm{g} / \mathrm{mL})$ in order to investigate the cytotoxic effect of PHC. After incubation, 
$20 \mu \mathrm{L} /$ well MTT (Amresco Inc., USA) solution ( $5 \mathrm{mg} / \mathrm{mL}$ ) was added and incubated for $4 \mathrm{~h}$. The medium was aspirated and replaced with $150 \mu \mathrm{L} /$ well dimethyl sulfoxide solution (DMSO). The plates were shaken for $10 \mathrm{~min}$, and absorbance was determined at $490 \mathrm{~nm}$ using an automated microplate reader (RT-6000, Shenzhen Rayto Life Science Limited Company, China). Each assay was performed on five plates.

\section{Western blot analysis}

Equal amounts of proteins $(40 \mu \mathrm{g})$ were loaded onto SDS-polyacrylamide gels, transferred to nylon membranes, and incubated with primary antibody overnight at $4^{\circ} \mathrm{C}$. Excess antibody was then removed by washing the membranes in PBS-0.05\% Tween-20, and the membranes were incubated in secondary antibodies for $30 \mathrm{~min}$. After washing in PBS-0.05\% Tween 20, the bands were detected by enhanced chemiluminescence and the density of the individual bands was quantified by densitometry using the AlphaEase FC software (Alpha Innotech Inc., USA).

\section{Measurement of MDA and SOD}

Cells were collected to examine MDA content and SOD activity. Absorbance was measured at $532 \mathrm{~nm}$ (MDA) and $550 \mathrm{~nm}$ (SOD), on a DU-530 spectrophotometer (Beckman Instruments Inc., USA). MDA was measured after reaction with thiobarbituric acid using the MDA assay kit; SOD was determined by a method using inhibition of superoxide anions produced by the action of xanthine oxidase on xanthine using the SOD assay kit. MDA concentrations are reported as $\mathrm{nmol} / \mathrm{mL}$. SOD activities are reported in units per milliliter $(\mathrm{U} / \mathrm{mL})$.

\section{Statistical analysis}

Data are reported as means $\pm S D$. Analysis of variance (ANOVA) and the Student-Newman-Keuls Qtest were used for statistical comparison of values among all groups. A significant difference was presumed for a probability value of $<0.05$.

\section{Results}

\section{LPS-induced HPMEC muscarinic receptor 3 activation}

We identified muscarinic receptor subtypes $M_{1}-M_{4}$ in HPMEC, and found that the $M_{3}$ receptor was the most highly expressed of the four (Figure 1). We then measured $M_{3}$ receptor expression in LPS-induced HPMEC at 5-min time points from 5 to $30 \mathrm{~min}$. It was shown that, in a time-dependent manner, maximum expression of $\mathrm{M}_{3}$ receptor was induced at $5 \mathrm{~min}$ and then declined gradually from 10 to $30 \mathrm{~min}$ (Figure 2).

\section{MTT assays}

Mitochondrial succinate dehydrogenase in living cells converts MTT into visible formazan crystals during

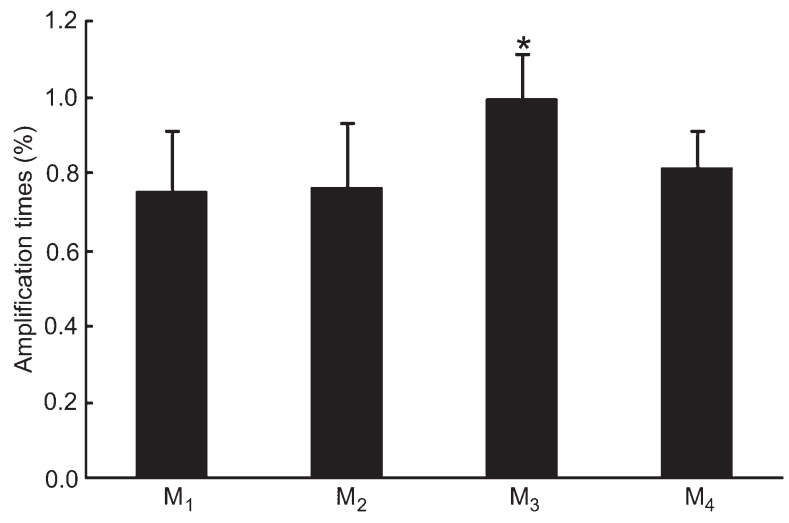

Figure 1. Expressions of different types of muscarinic receptors in human pulmonary microvascular endothelial cells $(n=5) . M_{3}$ receptor had the highest expression among the four subtypes $\left(M_{1}-M_{4}\right)$. Therefore, we tested $M_{3}$ receptor expression in the subsequent experiment. ${ }^{*} \mathrm{P}<0.05$, compared with $\mathrm{M}_{1}, \mathrm{M}_{2}$, and $\mathrm{M}_{4}$ receptors (ANOVA)

incubation. The formazan crystals were then solubilized in DMSO. However, these reactions do not occur in dead cells. Absorbance thus represents the number of surviving cells. As shown in Figure 3, cell survival significantly decreased after LPS challenge, and PHC $(200 \mu \mathrm{g} / \mathrm{mL})$ alone exerted no effect on cell survival. Compared with the LPS group, there was a measurable increase in absorbance in all PHC groups. However, the increase was significant only in the 2 and $1 \mu \mathrm{g} / \mathrm{mL} \mathrm{PHC}$ groups.

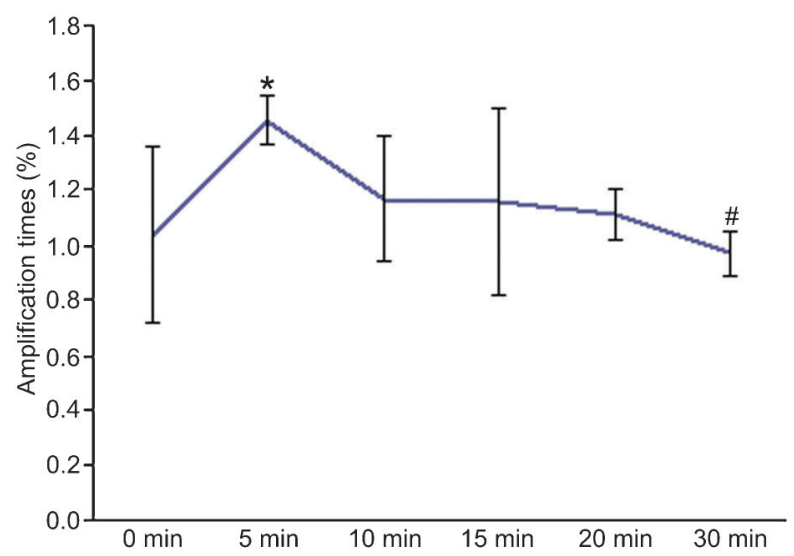

Figure 2. Changes of lipopolysaccharide-induced $M_{3}$ receptor activation with time in human pulmonary microvascular endothelial cells $(n=3) . M_{3}$ receptor had the highest expression at $5 \mathrm{~min}$, then attenuated gradually from 10 to $30 \mathrm{~min}$. ${ }^{*} \mathrm{P}<0.05$, compared with $0 \mathrm{~min}$; ${ }^{\#}<0.05$, compared with $5 \mathrm{~min}$ (ANOVA). 


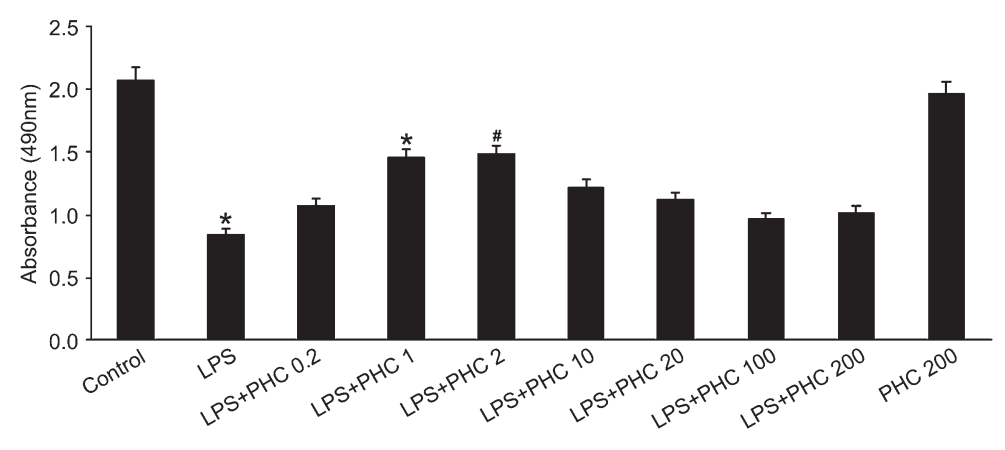

Figure 3. Comparison of methyl thiazolyl tetrazolium (MTT) assay results $(n=5)$. PHC: penehyclidine hydrochloride $(0.2-200 \mu \mathrm{g} / \mathrm{mL}){ }^{*} \mathrm{P}<0.05$, compared with control group; ${ }^{\#} \mathrm{P}<0.05$, compared with lipopolysaccharide (LPS) group (ANOVA).

\section{Dose and time of PHC on $\beta$-arrestin-1 expression in LPS-induced HPMEC}

We chose 4 concentrations of $\mathrm{PHC}$ to determine the optimal dose of PHC on $\beta$-arrestin-1 expression in LPS-induced HPMEC. It was demonstrated that $2 \mu \mathrm{g} / \mathrm{mL}$ PHC upregulated expression of $\beta$-arrestin-1 most significantly (Figure 4).

Then, the time point of $\mathrm{PHC}$ on $\beta$-arrestin- 1 expression in LPS-induced HPMEC was observed. The effect of PHC on $\beta$-arrestin-1 expression in LPS-induced HPMEC decreased gradually from 0.5 to $24 \mathrm{~h}$. The effect of $\mathrm{PHC}$ on $\beta$-arrestin-1 expression in LPS-induced HPMEC was measured at 5 -min time points from 5 to $30 \mathrm{~min}$. Maximum expression of $\beta$-arrestin- 1 was induced between 10 and 15 min as shown (Figure 5).
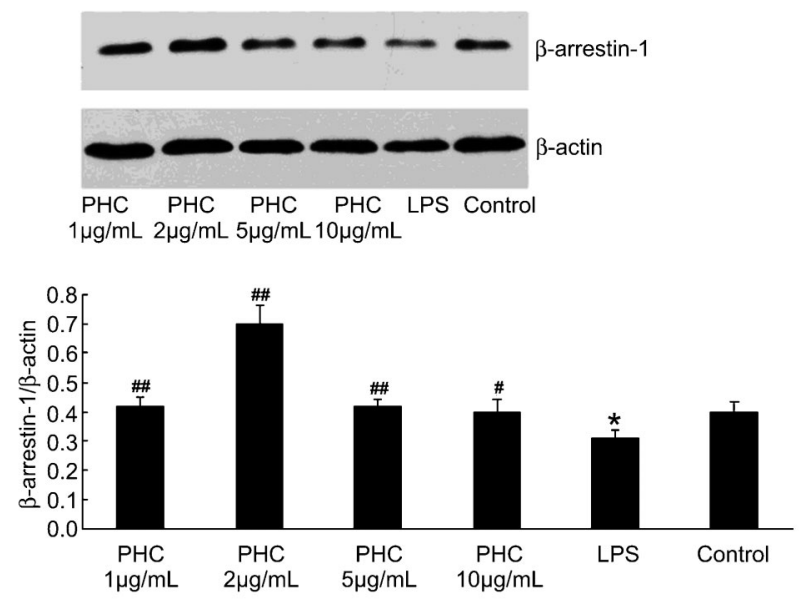

Figure 4. Effect of different concentrations of penehyclidine hydrochloride (PHC) on $\beta$-arrestin-1 expression in lipopolysaccharide (LPS)-induced human pulmonary microvascular endothelial cells (HPMEC) $(n=3)$. HPMEC were pretreated with different concentrations of $\mathrm{PHC}(1,2,5$, and $10 \mu \mathrm{g} / \mathrm{mL})$ for $1 \mathrm{~h}$ and stimulated with $0.1 \mu \mathrm{g} / \mathrm{mL}$ LPS for another $24 \mathrm{~h}$. Equal amounts of protein in the cell lysates were electrophoresed and the levels of protein were determined using specific antibodies. PHC at a concentration of $2 \mu \mathrm{g} / \mathrm{mL}$ upregulated expression of $\beta$-arrestin-1 most significantly. ${ }^{*} \mathrm{P}<0.01$, compared with control group; ${ }^{\#} \mathrm{P}<0.05,{ }^{\# \#} \mathrm{P}<0.01$, compared with LPS group (ANOVA).

\section{LPS-induced oxidative stress and its modulation by PHC}

To assess the antioxidant effects of $\mathrm{PHC}$, we preincubated cells with $2 \mu \mathrm{g} / \mathrm{mL}$ PHC for $1 \mathrm{~h}$, followed by $0.1 \mu \mathrm{g} / \mathrm{mL}$ LPS treatment for $1 \mathrm{~h}$. Compared with the control group, the MDA content in cells was remarkably increased and SOD activity was significantly decreased in the LPS group (both $\mathrm{P}<0.01$ ). Two microgram per milliliter PHC pretreatment markedly decreased LPSinduced MDA content and enhanced SOD activities (Figure 6). In addition, PHC alone had no effect on basal oxidative status in cells.

\section{Discussion}

The present study was undertaken to elucidate the biological effect of PHC on $\beta$-arrestin- 1 expression, MDA production and SOD activity in LPS-induced HPMEC. To our knowledge, this is the first report regarding the effect of PHC on $\beta$-arrestin- 1 expression at the cellular level.

GPCRs are the largest family of cell surface receptors. GPCRs can be activated by multiple ligands and exhibit the capacity to couple to numerous intracellular signal transduction pathways (18). Oxidative stresses have recently been shown to be generated by agonists of several members of the GPCR superfamily (19). Muscarinic acetylcholine receptors, which are linked to a variety of intracellular second messenger systems through G-proteins, belong to the GPCR superfamily. Muscarinic receptors can regulate numerous central and peripheral physiological functions including control of memory, arousal, motor activity, and heart rate (20). Muscarinic receptors are divided into five distinct subtypes $M_{1}-M_{5}$, and we determined $M_{1}-M_{4}$ subtypes in HPMEC in this study. The $M_{3}$ receptor was the most highly expressed of the four subtypes. Furthermore, $\mathrm{M}_{3}$ receptor activation occurred at 5 min after LPS challenge, at the same time as an increase in MDA level and reduction in SOD activity, which indicated lipid peroxidation damage emerged at $60 \mathrm{~min}$ and suggested that $M_{3}$ activation may lead to oxidative stress generation in LPS-induced HPMEC.

$\beta$-arrestins are scaffolding proteins originally noted for their role in GPCR desensitization (21). Recent studies 

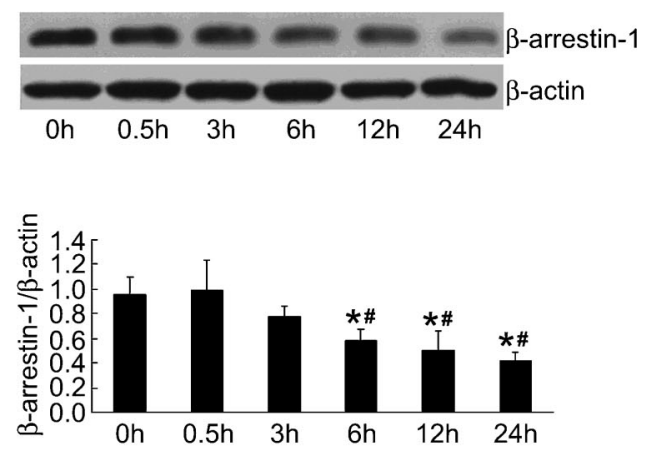
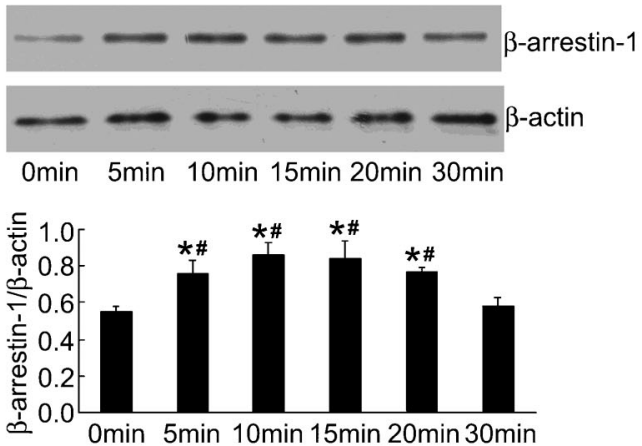

Figure 5. Effect of penehyclidine hydrochloride (PHC) on $\beta$-arrestin-1 expression with time in lipopolysaccharide (LPS)-induced human pulmonary microvascular endothelial cells (HPMEC) $(n=3)$. HPMEC were pre-incubated with $2 \mu \mathrm{g} / \mathrm{mL}$ PHC for $1 \mathrm{~h}$ and treated with $0.1 \mu \mathrm{g} / \mathrm{mL}$ LPS for different times. This figure is representative of the experiment. $\beta$-arrestin- 1 protein expression is reported as respective absorbance/ $\beta$-actin absorbance. $\beta$-arrestin- 1 had the highest expression at 10 and 15 min. ${ }^{*} \mathrm{P}<0.01$, compared with $0 \mathrm{~h}$; ${ }^{\#} \mathrm{P}<0.01$, compared with $0.5 \mathrm{~h}$; ${ }^{*} \mathrm{P}<0.01$, compared with $0 \mathrm{~min}$; ${ }^{\#} \mathrm{P}<0.01$, compared with $30 \mathrm{~min}$ (ANOVA).

have suggested that $\beta$-arrestins also play a role in cell signaling pathways, and in gene expression $(22,23)$. The muscarinic receptor is a kind of GPCR, while $\beta$-arrestin-1 is known as a terminator of GPCR signaling. It is possible that $\beta$-arrestin-1 decreased oxidative stress through blocking $M_{3}$ receptors and its downstream signal pathway.

MDA is suggested to indicate induction of ROS activity and oxidative tissue damage (24). In this study, reduction in MDA concentration indicated less lipid peroxidation damage in the PHC group compared to the LPS group. SOD is the major intracellular antioxidant with multiple biological functions (25). With an increase in the antioxidant enzyme SOD, it could reasonably be expected that cellular biochemical markers of oxidative stress would be reduced after PHC treatment. As assessed by the MTT assay, the effects of PHC on these indices were not attributable to PHC cytotoxicity.

It has been reported that anisodamine, a widely prescribed muscarinic receptor antagonist, could exert antiflammatory effects through upregulating $\beta$-arrestin-1
(26). PHC, which has fewer cardiovascular side effects than other anticholinergics, may exert antioxidant effects through upregulating $\beta$-arrestin-1.

Yan et al. (27) studied the effect of PHC on strips of intestine isolated from guinea pigs, and found that $\mathrm{PHC}$ can effectively relieve intestine spasm in vitro at concentrations of $0.2,2.0,20.0 \mu \mathrm{g} / \mathrm{mL}$. We also carried out MTT experiments to determine the optimum concentration based on the above study, and the concentrations of PHC (1 to $10 \mu \mathrm{g} / \mathrm{mL}$ ) were chosen for $\beta$-arrestin-1 measurement. From the results of Western blot analysis, $2 \mu \mathrm{g} / \mathrm{mL}$ PHC had a significant protective effect on LPSinduced HPMEC compared with the other doses. Furthermore, the time of maximum peak of $\mathrm{PHC}$ on $\beta$ arrestin-1 expression in LPS-induced HPMEC was between 10 and 15 min.

We conclude that $\mathrm{PHC}$ intervention had a beneficial protective effect, at an appropriate dose, on LPS-induced HPMEC. Its mechanisms of action probably involve the upregulation of $\beta$-arrestin-1 expression and suppression of lipid peroxidation.
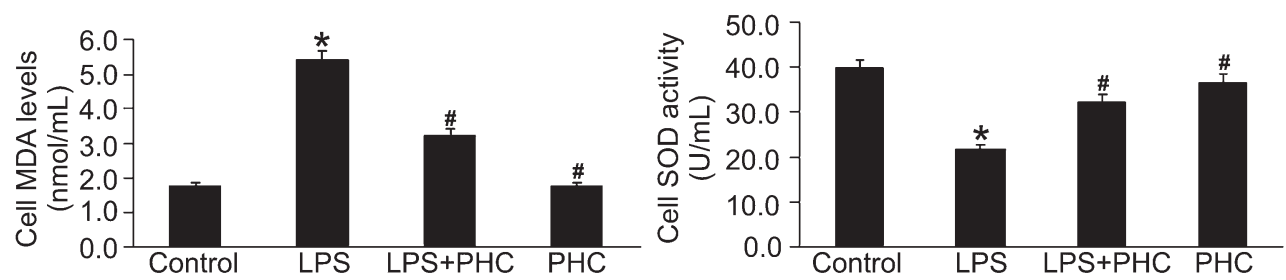

Figure 6. Inhibition of lipopolysaccharide (LPS)-induced malondialdehyde (MDA) increase and superoxide dismutase (SOD) decrease by penehyclidine hydrochloride (PHC) $(n=5)$. Human pulmonary microvascular endothelial cells were pre-incubated with $\mathrm{PHC}$ for $1 \mathrm{~h}$ and treated with $0.1 \mu \mathrm{g} / \mathrm{mL}$ LPS for $1 \mathrm{~h}$. LPS treatment significantly induced MDA increase and SOD decrease, which was attenuated by $\mathrm{PHC}$ pretreatment. In addition, $\mathrm{PHC}$ alone had no effect on basal MDA and SOD levels. Data are reported as means $\pm S D$. ${ }^{*} \mathrm{P}<0.01$, compared to control; ${ }^{\#} \mathrm{P}<0.05$, compared to LPS treatment (ANOVA). 
However, the current study has some limitations that need to be addressed. The effect of PHC on oxidative stress is attributable to either the inhibitory effects of $\mathrm{PHC}$ on $M_{3}$ receptors, or blocking $M_{3}$ receptor's downstream signal pathway through upregulating $\beta$-arrestin-1. Future studies would benefit from assessments of $\beta$-arrestin- 1 or $\mathrm{M}_{3}$ receptor function using specific siRNAs.

\section{References}

1. Pereira CE, Heck TG, Saldiva PH, Rhoden CR. Ambient particulate air pollution from vehicles promotes lipid peroxidation and inflammatory responses in rat lung. Braz $\mathrm{J}$ Med Biol Res 2007; 40: 1353-1359, doi: 10.1590/S0100879X2006005000164.

2. Del Rio D, Stewart AJ, Pellegrini N. A review of recent studies on malondialdehyde as toxic molecule and biological marker of oxidative stress. Nutr Metab Cardiovasc Dis 2005; 15: 316-328, doi: 10.1016/j.numecd.2005.05. 003.

3. Gao F, Kinnula VL, Myllarniemi M, Oury TD. Extracellular superoxide dismutase in pulmonary fibrosis. Antioxid Redox Signal 2008; 10: 343-354, doi: 10.1089/ars.2007.1908.

4. Hara MR, Kovacs JJ, Whalen EJ, Rajagopal S, Strachan RT, Grant W, et al. A stress response pathway regulates DNA damage through beta2-adrenoreceptors and betaarrestin-1. Nature 2011; 477: 349-353, doi: 10.1038/ nature10368.

5. Pierce KL, Lefkowitz RJ. Classical and new roles of betaarrestins in the regulation of G-protein-coupled receptors. Nat Rev Neurosci 2001; 2: 727-733, doi: 10.1038/ 35094577.

6. Hanson SM, Vishnivetskiy SA, Hubbell WL, Gurevich VV. Opposing effects of inositol hexakisphosphate on rod arrestin and arrestin2 self-association. Biochemistry 2008; 47: 1070-1075, doi: 10.1021/bi7021359.

7. Zhan X, Kaoud TS, Dalby KN, Gurevich VV. Nonvisual arrestins function as simple scaffolds assembling the MKK4-JNK3alpha2 signaling complex. Biochemistry 2011; 50: 10520-10529, doi: $10.1021 / \mathrm{bi} 201506 \mathrm{~g}$.

8. Dalle S, Ravier MA, Bertrand G. Emerging roles for betaarrestin-1 in the control of the pancreatic beta-cell function and mass: new therapeutic strategies and consequences for drug screening. Cell Signal 2011; 23: 522-528, doi: 10.1016/j.cellsig.2010.09.014.

9. Porter KJ, Gonipeta B, Parvataneni S, Appledorn DM, Patial $S$, Sharma D, et al. Regulation of lipopolysaccharideinduced inflammatory response and endotoxemia by betaarrestins. J Cell Physiol 2010; 225: 406-416, doi: 10.1002/ jcp.22289.

10. Basher F, Fan H, Zingarelli B, Borg KT, Luttrell LM, Tempel $\mathrm{GE}$, et al. Beta-arrestin 2: a negative regulator of inflammatory responses in polymorphonuclear leukocytes. Int $J$ Clin Exp Med 2008; 1: 32-41.

11. Fan H, Luttrell LM, Tempel GE, Senn JJ, Halushka PV, Cook JA. Beta-arrestins 1 and 2 differentially regulate LPSinduced signaling and pro-inflammatory gene expression. Mol Immunol 2007; 44: 3092-3099, doi: 10.1016/ j.molimm.2007.02.009.

12. Han $\mathrm{XY}$, Liu H, Liu CH, Wu B, Chen LF, Zhong BH, et al.

\section{Acknowledgments}

Research supported by the National Natural Science Foundation of China (\#81101408) and Special Fund of Fundamental Scientific Research Business Expense for Higher School of Central Government (\#111169).

Synthesis of the optical isomers of a new anticholinergic drug, penehyclidine hydrochloride (8018). Bioorg Med Chem Lett 2005; 15: 1979-1982, doi: 10.1016/j.bmcl.2005. 02.071.

13. Wang YA, Zhou WX, Li JX, Liu YQ, Yue YJ, Zheng JQ, et al. Anticonvulsant effects of phencynonate hydrochloride and other anticholinergic drugs in soman poisoning: neurochemical mechanisms. Life Sci 2005; 78: 210-223, doi: 10.1016/ j.Ifs.2005.04.071.

14. Tao YJ, Chen JR, Zhu J, Yao J, Li KS, Zhang Y. The clinical applications of penehyclidine hydrochloride in patients with AECOPD. Chin J Emerg Med 2006; 15: 255-262.

15. Shen W, Gan J, Xu S, Jiang G, Wu H. Penehyclidine hydrochloride attenuates LPS-induced acute lung injury involvement of NF-kappaB pathway. Pharmacol Res 2009; 60: 296-302, doi: 10.1016/j.phrs.2009.04.007.

16. Zhan J, Zhang ZZ, Chen C, Chen K, Wang YL. Penehyclidine hydrochloride attenuates LPS-induced iNOS production by inhibiting p38 MAPK activation in endothelial cells. Mol Biol Rep 2012; 39: 1261-1265, doi: 10.1007/s11033-011-0857-4.

17. Zhao M, Wimmer A, Trieu K, Discipio RG, Schraufstatter IU. Arrestin regulates MAPK activation and prevents $\mathrm{NADPH}$ oxidase-dependent death of cells expressing CXCR2. J Biol Chem 2004; 279: 49259-49267, doi: 10.1074/jbc. M405118200.

18. Ferguson SS. Using green fluorescent protein to understand the mechanisms of G-protein-coupled receptor regulation. Braz J Med Biol Res 1998; 31: 1471-1477, doi: 10.1590/S0100-879X1998001100016.

19. Burns RN, Moniri NH. Agonist- and hydrogen peroxidemediated oxidation of the beta2 adrenergic receptor: evidence of receptor s-sulfenation as detected by a modified biotin-switch assay. J Pharmacol Exp Ther 2011; 339: 914921, doi: 10.1124/jpet.111.185975.

20. Caulfield MP, Birdsall NJ. International Union of Pharmacology XVII. Classification of muscarinic acetylcholine receptors. Pharmacol Rev 1998; 50: 279-290.

21. Ma L, Pei G. Beta-arrestin signaling and regulation of transcription. J Cell Sci 2007; 120: 213-218, doi: 10.1242/ jcs.03338.

22. Bitto A, Minutoli L, David A, Irrera N, Rinaldi M, Venuti FS, et al. Flavocoxid, a dual inhibitor of COX-2 and 5-LOX of natural origin, attenuates the inflammatory response and protects mice from sepsis. Crit Care 2012; 16: R32, doi: 10.1186/1364-8535-16-R32.

23. DeFea KA. Beta-arrestins as regulators of signal termination and transduction: how do they determine what to scaffold? Cell Signal 2011; 23: 621-629, doi: 10.1016/ j.cellsig.2010.10.004.

24. Gawel S, Wardas M, NiedworokE, Wardas P. [Malondialdehyde 
(MDA) as a lipid peroxidation marker]. Wiad Lek 2004; 57: 453-455.

25. Macarthur H, Westfall TC, Riley DP, Misko TP, Salvemini D. Inactivation of catecholamines by superoxide gives new insights on the pathogenesis of septic shock. Proc Natl Acad Sci U S A 2000; 97: 9753-9758, doi: 10.1073/pnas.97.17.9753.

26. Liu C. The anti-shock effect of anisodamine involves the novel ways for the activating of $\alpha 7$ nicotinic acetylcholine receptor and the increasing of $\beta$-arrestins expression. [PhD Thesis]: Second Military Medical University, Shang Hai, China; 2008

27. Yan XY, Mo ZJ, Liu P. Effects of penehyclidine hydrochloride on intestinal spasm of guinea pigs in vitro. West China J Pharm Sci 2005; 20: 46-47. 